\title{
PEMBERDAYAAN MASYARAKAT DESA RONGDALEM KECAMATAN OMBEN KABUPATEN SAMPANG SEBAGAI UPAYA MEWUJUDKAN DESA MANDIRI
}

\author{
Dwi Muryanto" ${ }^{\text {), I Wayan Nuada }}{ }^{2)}$, Bachrul Amiq ${ }^{3)}$ \\ ${ }^{1}$ Fakultas Teknik, Universitas Dr. Soetomo Surabaya \\ ${ }^{2}$ Fakultas Ilmu Administrasi, Universitas Dr. Soetomo Surabaya \\ ${ }^{3}$ Fakultas Hukum, Universitas Dr. Soetomo Surabaya \\ Email: dwi.muryanto@unitomo.ac.id
}

\begin{abstract}
Abstrak
Desa Rong Dalem, Sampang-Madura berupaya menyelesaikan berbagai masalah sosial dan lingkungan di wilayahnya secara bijak. Masalah tersebut adalah: kurangnya kesadaran pendidikan, minimnya sarana dan prasarana kesehatan, kurangnya inisiatif dan kreativitas masyarakat dalam memanfaatkan potensi desa dan lingkungannya, serta teknologi dalam pemenuhan kebutuhan air bersih. Untuk masalah pendidikan, masyarakat hanya menempuh pendidikan sampai tingkat Sekolah Dasar saja meskipun memiliki kemampuan finansial. Masyarakat lebih berorientasi menempuh pendidikan di pondok pesantren dan mencari pekerjaan dibanding sekolah. Untuk masalah kesehatan, masyarakat kurang memahami kondisi kesehatan pribadi dan keluarga serta minimnya sarana dan prasarana kesehatan. Untuk hasil bumi seperti kacang, siwalan, umbi-umbian dan lain-lain masyarakat belum mampu mengolah secara maksimal. Masyarakat lebih tertarik mengembangkan tanaman tembakau saja. Sedangkan untuk masalah kebutuhan air bersih, pada musim kemarau kesulitan sumber air, tetapi pada musim penghujan air melimpah namun tidak terserap tanah. Tujuan kegiatan ini adalah: memberi wawasan kepada masyakat untuk sadar pendidikan, sadar tentang potensi diri dan lingkungannya sehingga termotivasi untuk membangun, mengembangkan, dan memberdayakan masyarakat dan lingkungan menuju desa mandiri. Metode pelaksanaan kegiatan ini adalah dengan melakukan penyuluhan dan pelatihan. Hasil yang dicapai dari kegiatan ini adalah masyarakat Desa Rong Dalem sadar dan memahami pentingnya pendidikan, pengembangan potensi diri dan lingkungannya, serta mampu mengelola sumber daya air dengan mempraktekkan cara pembuatan biopori dan saluran drainase.
\end{abstract}

Kata kunci: kesadaran, potensi, pengelolaan, pengembangan, mandiri

\begin{abstract}
Rong Dalem Village, Sampang-Madura strives to resolve various social and environmental problems in its area wisely. These problems are: lack of awareness of education, lack of health facilities and infrastructure, lack of initiative and creativity of the community in utilizing the potential of the village and its environment, and technology in meeting the needs of clean water. For the problem of education, people only elementary school even though they have financial ability. The community is more oriented to education in Islamic boarding schools and looking for work than schools. For health problems, the public does not understand the conditions of personal and family health and the lack of health facilities and infrastructure. For crops potential the community has not been able to process optimally. People are more interested in developing tobacco plants. Whereas for the problem of clean water needs, during the dry season water sources are difficult, but in the rainy season the water is abundant but not absorbed by the soil. The purpose of this activity is: to give insight to the community to be aware of education, be aware of their potential and environment so that they are motivated to build, develop, and empower people and the environment towards independent villages. The method of implementing this activity is by conducting counseling and training. The results of this activity are that the
\end{abstract}


community of Rong Dalem are aware and understand the importance of education, the development of their own potential and environment, and are able to manage water resources by practicing how to make biopores and drainage channels.

Keywords: awareness, potential, management, development, independent

\section{PENDAHULUAN}

Rongdalem merupakan salah satu desa atau wilayah yang berada di Kecamatan Omben, Kabupaten Sampang Pulau Madura. Secara geografis, Desa Rongdalem berbatasan langsung dengan wilayah Kecamatan Kedungdung di sisi barat, dan di sisi timur berbatasan dengan Desa Rapa Laok. Sedangkan di sisi utara berbatasan dengan Desa Pandan dan disisi selatan berbatasan dengan Desa Jrangoan. Desa ini terletak pada dataran rendah yang memilki luas wilayah 6,65 $\mathrm{Km} 2$ dengan tinggi wilayah 95 meter dari permukaan laut. Tak heran apabila jenis tanah pada desa Rong Dalem ini didominasi oleh tanah kering yang luas wilayahnya mencapai $751 \mathrm{Ha}$ dan tanah sawah hanya memiliki luas $104 \mathrm{Ha}$.

Pada Desa Rong Dalem ini terbagi menjadi 3 (tiga) dusun, sehingga Desa Rong Dalem ini memiliki 3 (tiga) Kepala Dusun, 1 (satu) Kepala Desa dan Seketariat Desa untuk mengatur sistem pemerintahan yang ada. Selain 5 (lima) anggota pemerintah desa ini, juga terdapat Kepala Urusan Keuangan, Kepala Umum Desa yang dibantu dengan 1 (satu) Modin. Namun, untuk pelaksanaan kegiatan pemerintahan Desa Rong dalem tidak memiliki Balai Desa atau Kantor Pemerintahan. Pelaksanaan kegiatan pemerintahan dilaksanakan di rumah masingmasing perangkat desa.

Di tahun 2016 Desa Rong Dalem ini memiliki 4.514 jiwa penduduk yang di dominasi oleh 2.277 jiwa penduduk perempuan dan 998 jiwa laki-laki. Adapun rata-rata tingkat pertumbuhan kelahiran penduduk mencapai 10,19\% dengan jumlah 46 orang dan rata-rata kematian mencapai $0,89 \%$ dengan jumlah 4 penduduk. Sebagian besar masyarakat beragama Islam. Adapun mata pencaharian di Desa Rong Dalem ini yaitu pertanian yang dikontribusi oleh tanaman pangan sebanyak 771 rumah tangga dan 320 di perkebunan. Mata pencaharian masyarakat Desa Rong Dalem adalah petani kacang tanah dan petani tembakau. Untuk kerajinan tangan warga Desa Rong Dalem biasa membuat tikar anyam dan budeg atau tempat nasi yang dianyam.

Permasalahan penting yang ada di Desa Rong Dalem Kecamatan Omben Kabupaten Sampang adalah kurangnya kesadaran akan pendidikan, kurangya kesadaran akan kesehatan, kurangnya inisiatif dan kreativitas masyarakat dalam memanfaatkan potensi desa dan lingkungannya, serta pengetahuan dalam mencari solusi akan pemenuhan kebutuhan air bersih. Untuk masalah pendidikan, masih banyak masyarakat yang hanya menempuh pendidikan hanya sampai tingkat Sekolah Dasar saja. Meskipun mempunyai kemampuan finansial masyarakat lebih berorientasi menempuh pendidikan di pondok pesantren dan mencari pekerjaan dibanding sekolah. Untuk masalah kesehatan, masyarakat kurang memahami kondisi kesehatan pribadi, keluarga, dan lingkungan serta terbatasnya sarana dan prasarana kesehatan. Untuk masalah kreativitas, masyarakat masih kurang mampu mengolah dan mengembangkan hasil bumi yang ada seperti kacang, pohon siwalan, umbi-umbian dan lain-lain. Masyarakat hanya lebih tertarik mengebangkan potensi tanaman tembakau saja. Sedangkan untuk masalah pemenuhan kebutuhan air bersih, pada musim kemarau kesulitan sumber air, tetapi pada musim penghujan banjir dan air tidak terserap tanah. 


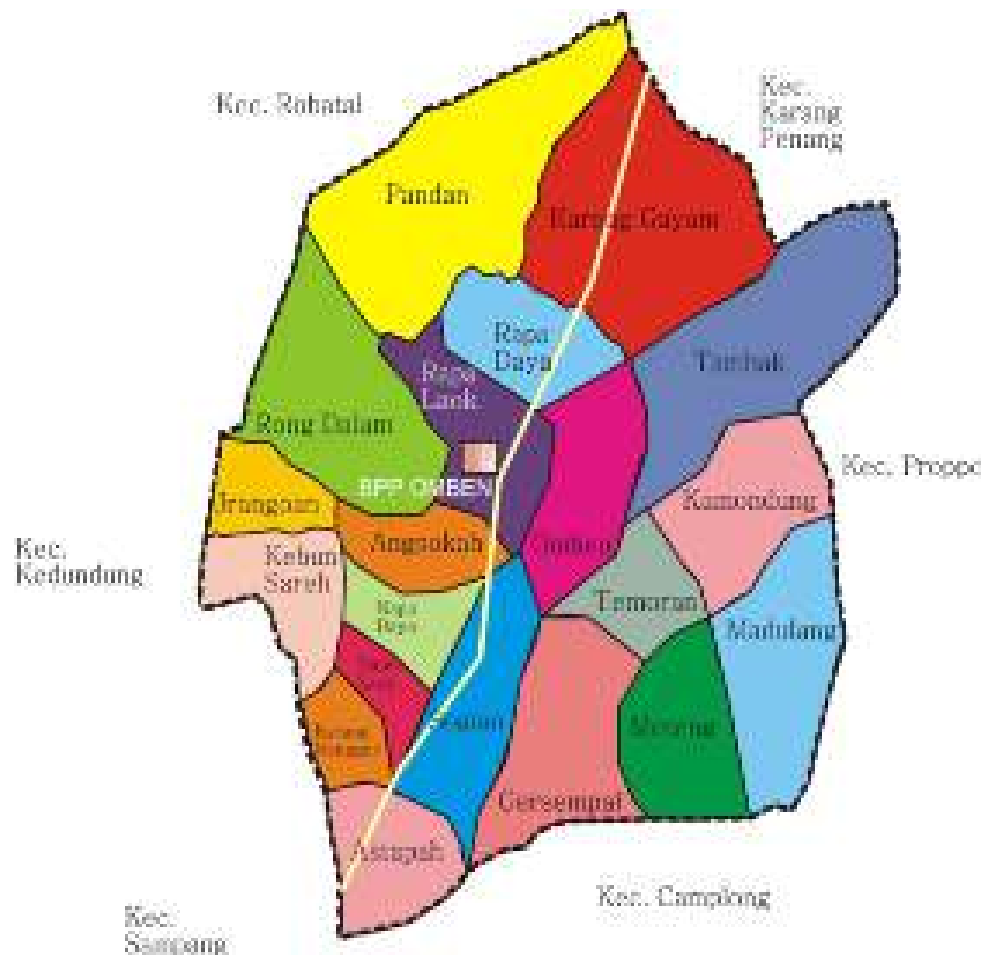

Gambar 1. Peta Wilayah Administrasi Kecamatan Omben

Sumber: Kabupaten Sampang Dalam Angka, 2017

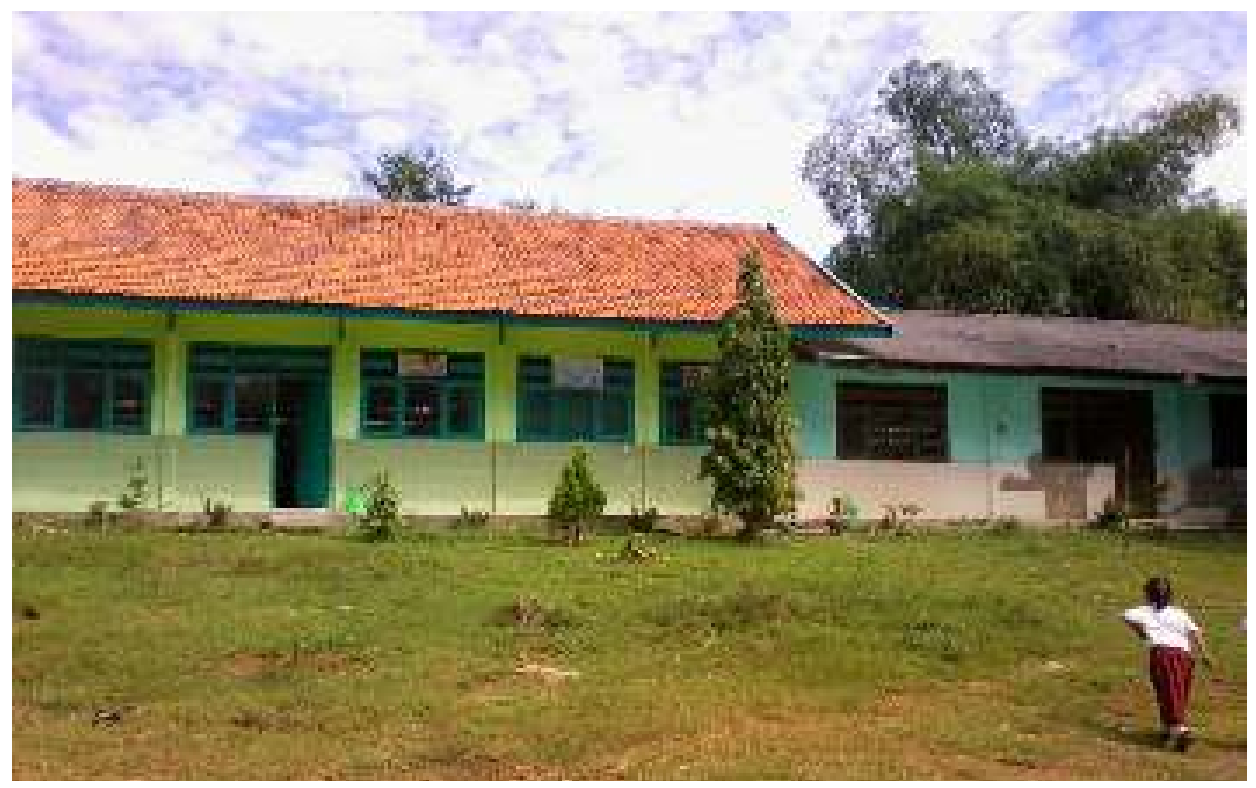

Gambar 2. Kondisi gedung Sekolah Dasar di Desa Rong dalem Sumber: Dokumentasi kegiatan, 2018 


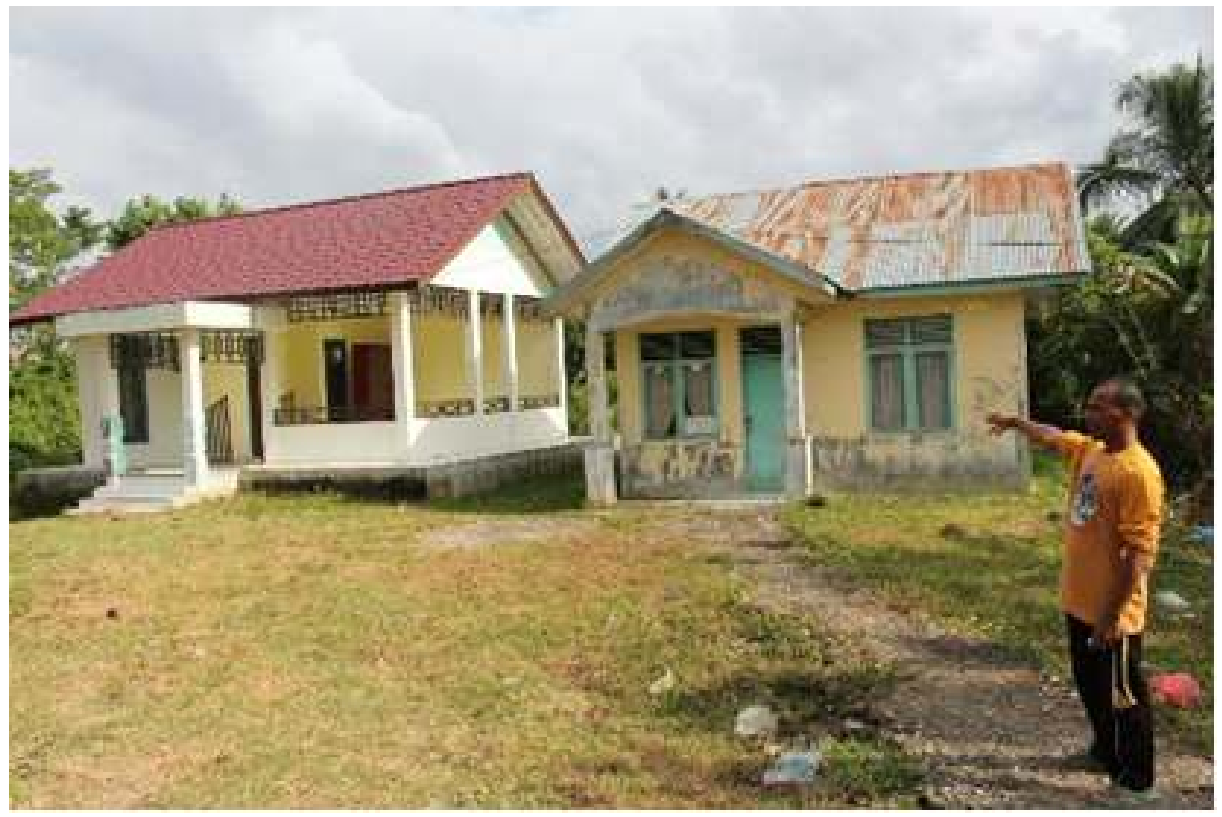

Gambar 3. Kondisi prasarana kesehatan Desa Rong Dalem Sumber: Dokumentasi kegiatan, 2018

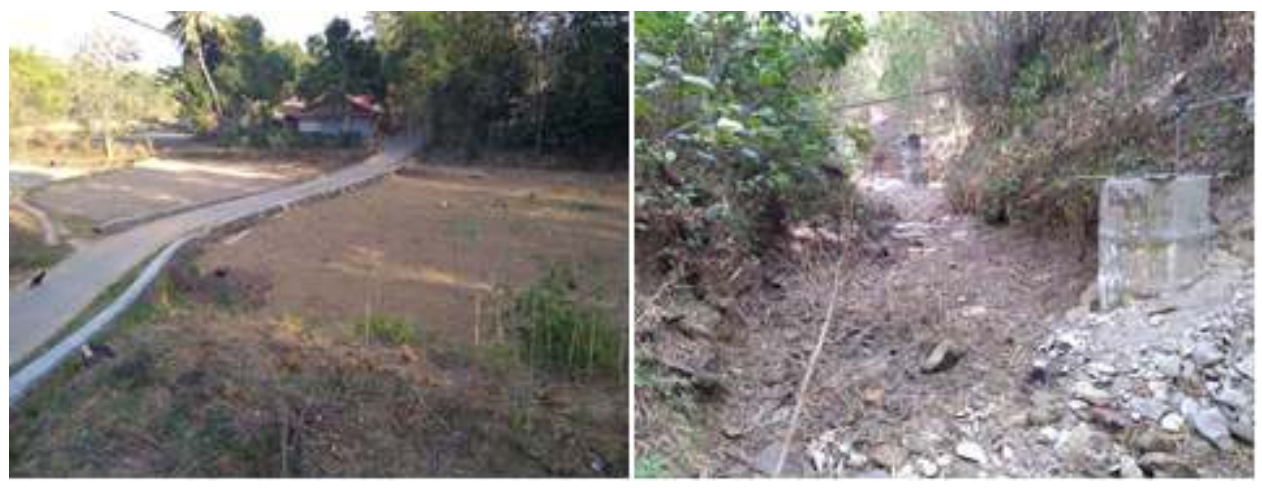

Gambar 4. Kondisi Infrastruktur Desa Rong Dalem Sumber: Dokumentasi kegiatan, 2018

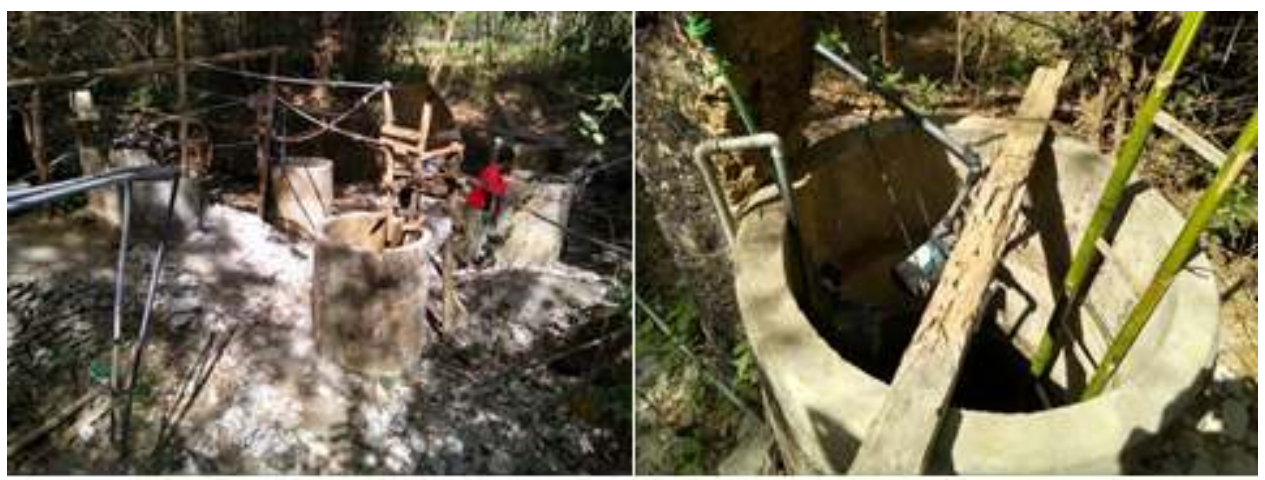

Gambar 5. Kondisi sumber air Desa Rong Dalem Sumber: Dokumentasi kegiatan, 2018 
Berdasarkan kondisi dan situasi tersebut maka permasalahan prioritas masyarakat mitra adalah sebagai berikut:

1. Kesadaran masyarakat tentang pendidikan masih kurang.

2. Kesadaran masyarakat tentang kesehatan masih kurang.

3. Masyarakat belum memiliki ketrampilan dalam memanfaatkan dan mengembangkan potensi desa dan lingkungannya.

4. Masyarakat belum memiliki pengetahuan dalam pengelolaan air bersih

5. Masyarakat Desa Rong Dalem memiliki potensi lahan pertanian dan pekarangan yang cukup luas namun belum dimanfaatkan secara optimal.

6. Pengolahan lahan hanya mengandalkan air hujan, sedangkan sumber air terbatas.

Dengan permasalahan yang dihadapi, maka prioritas utama yang harus dilakukan adalah sebagai berikut:

1. Memberi wawasan kepada masyakat akan pentingnya kualitas pendidikan.

2. Memberi wawasan kepada masyarakat akan pentingnya kesehatan keluarga dan lingkungan.

3. Memberi pendampingan dan pelatihan pengembangan keterampilan dalam memanfaatkan potensi masyarakat dan sumber daya alam yang ada.

4. Menyadarkan masyarakat bahwa air menjadi urusan/tanggungjawab setiap orang" ("Water is everybody business").

5. Perbaikan manajemen pengelolaan Sumber Daya Air.

\section{METODE PELAKSANAAN}

\section{Penyuluhan dan diskusi.}

Pada tahap ini masyarakat di lingkungan

Desa Rong Dalem bersama-sama diberi penyuluhan tentang materi pentingya pendidikan berkelanjutan, cara menjaga kesehatan keluarga dan lingkungan, cara memanfaatkan potensi sumber daya alam. Adapun solusi alternatif meminimalkan kekurangan air dan dampak banjir dengan pembuatan sumur resapan dan hunian yang berwawasan lingkungan. Teknologi yang ditawarkan sangat sederhana, tepat guna, mudah diterapkan, dan harganya sangat terjangkau, tetapi dampaknya luar biasa untuk menyelamatkan lingkungan khususnya menjaga kebersihan lingkungan, menjaga ketersediaan air tanah dan meminimalkan dampak banjir.

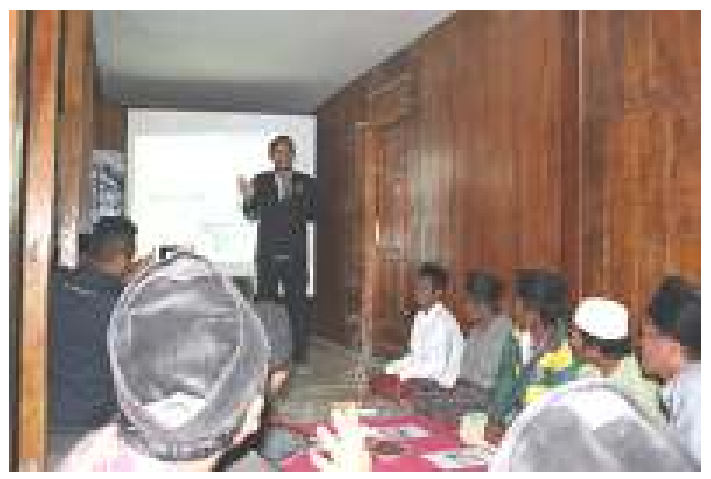

Gambar 6. Penyuluhan dan diskusi dengan masyarakat Desa Rong Dalem

Sumber: Dokumentasi kegiatan, 2018

Praktek langsung dengan pelatihan.

- Praktek mengajar oleh Tim Pelaksana bersama mahasiswa peserta KKN-PPM

- Cek kesehatan oleh Tim Pelaksana bersama mahasiswa peserta $\mathrm{KKN}$ PPM

- Praktek melatih pemanfaatan hasil sumber daya alam berupa pembuatan Ancang Aneka Rasa dll.

- Pembuatan Biopori, sumur resapan, dan tandon air. 


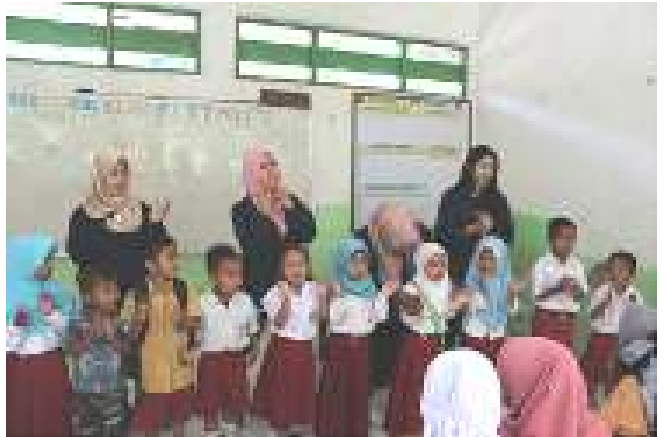

Gambar 7. Praktek mengajar di SDN Rong Dalem

Sumber: Dokumentasi kegiatan, 2018

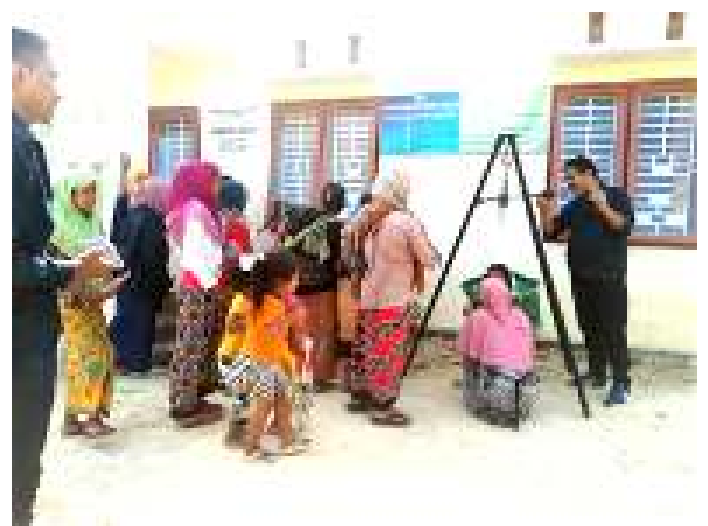

Gambar 8. Pendampingan kegiatan kesehatan masyarakat

Sumber: Dokumentasi kegiatan, 2018

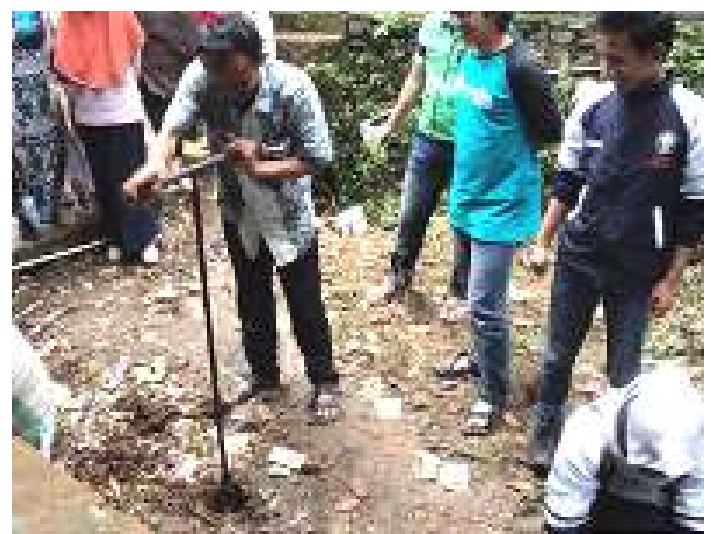

Gambar 9. Praktek pembuatan biopori

Sumber: Dokumentasi kegiatan, 2018

\section{Implementasi}

- Masyarakat sadar akan pendidikan berkelanjutan dan tertarik memasukkan anaknya ke lembaga pendidikan formal sampai jenjang tinggi.

- Masyarakat sadar akan pentingnya menjaga kesehatan keluarga dan lingkungan sehingga berpartisipasi dalam setiap kegiatan kesehatan masyarakat.

- Masyarakat aktif dan kreatif dalam mengembangkan keterampilan sehingga mendapatkan tambahan penghasilan, terutama pemanfaatan hasil sumber daya alam (pertanian)

- Pada setiap rumah sudah menerapkan pengelolahan sumber daya air dengan Biopori, sumur resapan, dan tandon air.

\section{Evaluasi}

Pada akhir pelaksanaan dilakukan evaluasi terhadap hasil kegiatan.

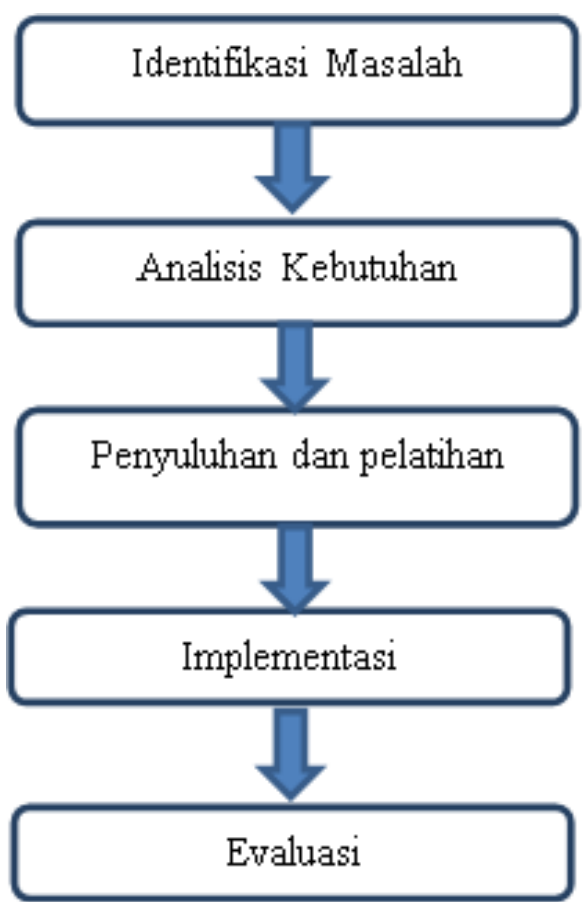

Gambar 2. Diagram Alir Tahapan Kegiatan

\section{HASIL DAN PEMBAHASAN}

Pelaksanaan program Pengabdian Masyarakat dimulai setelah dilakukan penandatanganan kontrak antara Ketua Pelaksana dengan Lembaga Pengabdian Masyarakat (LPM) Universitas Dr. Soetomo Surabaya. Langkah awal yang dilakukan 
adalah koordinasi dengan Mitra dan Mahasiswa KKN - PPM di Desa Rong Dalem Kecamatan Omben Kabupaten Sampang. Secara umum pelaksanaan program terdiri dari kegiatan di bidang pendidikan, kesehatan, pemberdayaan masyarakat, UMKM, dan infra struktur. Secara rinci pelaksanaan program Pengabdian Masyarakat adalah sebagai berikut:

\section{A. Bidang Pendidikan}

- Kondisi Awal

Warga masyarakat di Desa Rong Dalem belum memahami akan pentingnya pendidikan berkelanjutan. Mereka masih mengutamakan mencari pekerjaan dan menghasilkan uang daripada harus menempuh pendidikan formal.

- Kondisi Akhir

Setelah pelaksanaan program penyuluhan masyarakat menjadi sadar akan pentingnya pendidikan berkelanjutan dan ada upaya untuk me-sekolahkan anak dan keluarganya ke lembaga pendidikan formal mulai SD, SMP, SMA dan bahkan ke Perguruan Tinggi.

\section{B. Bidang Kesehatan}

- Kondisi Awal

Warga masyarakat di Desa Rong Dalem kurang memahami akan pentingnya menjaga kesehatan keluarga dan lingkungan. Mereka juga jarang atau tidak pernah melakukan tindakan preventif terhadap kesehatan. Ketika terserang penyakit, mereka baru berobat dan memeriksakan diri.

- Kondisi Akhir

Setelah pelaksanaan program penyuluhan masyarakat menjadi sadar akan pentingnya menjaga kesehatan keluarga dan lingkungannya serta rutin memeriksakan diri di Polindes setempat dengan motto "Lebih Baik Mencegah Daripada Mengobati"

\section{Bidang UMKM dan Pemberdayaan Masyarakat}

- Kondisi Awal

Warga masyarakat di Desa Rong Dalem kurang tertarik untuk mengembangkan potensi diri dan hasil sumber daya alam. Mereka hanya memanfaatkan secara konservatif sebagai pengisi waktu luang saja

- Kondisi Akhir

Setelah pelaksanaan program penyuluhan dan pelatihan keterampilan masyarakat menjadi sadar dan tertarik untuk mengembangkan potensi diri dengan berlatih keterampilan, mengolah hasil sumber daya alam menjadi barang yang bernilai ekonomis, seperti : hasil pertanian kacang dibuat makanan Ancang Aneka Rasa dan bernilai jual, buah dan air siwalan dapat dijadikan Nata de Coco dengan aneka rasa dan sebagainya

\section{Bidang Infrastruktur}

- Kondisi Awal

Warga masyarakat di Desa Rong Dalem kurang memahami tentang pentingnya hunian berwawasan lingkungan terkait pemanfaatan sumber daya air. Mereka masih kurang pengetahuan/memahami cara pengelolaan sumber daya air yang ada

- Kondisi Akhir

Setelah pelaksanaan program penyuluhan/pelatihan pemanfaatan sumber daya air, warga masyarakat Desa Rong Dalem mulai sadar akan pentingnya pengelolaan sumber daya air yang ada dan ada upaya menerapkan sumur resapan dan saluran drainase serta tandon air 


\section{KESIMPULAN}

1. Implementasi pembangunan desa memerlukan sumberdaya desa yang memadai untuk dapat mencapai desa mandiri, partisipatif dan berdaya.

2. Diperlukan upaya memandirikan desa dengan mengoptimalkan potensi dan sumberdaya yang ada dengan meningkatkan kapasitas pemerintahan desa dalam melakukan pemberdayaan masyarakat desa.

3. Pemberdayaan masyarakat desa diselenggarakan dengan strategi partisipatif dalam koridor good village governance (kepemerintahan desa yang baik), dengan semangat membangun diri bersama (togetherness in collective action), penguatan modal sosial dalam upaya penyelenggaraan desa membangun.

4. Partisipasi masyaraakat akan dapat bertumbuh ketika masyarakat merasa membutuhkan dan mempersepsi bahwa aktivitas desa membangun adalah kebutuhan mereka, bukan kebutuhan kepala desa dan atau perangkat desa

\section{REFERENSI}

Badan Pusat Statistik, 2017. Kabupaten Sampang Dalam Angka 2017. Biro Pusat Statistik, Kabupaten Sampang.

Bisri, Muhamad, 2008, "Teknologi Konservasi Sumber Daya Air" Materi Pelatihan Tenaga Ahli Konstruksi SDA - Departemen Pekerjaan Umum, 2008

Direktorat Jendral Sumber Daya Air Departemen Pekerjaan Umum, 2006, "Pengelolaan Banjir", Jakarta

Mawardiani, 2012, "Analisis Faktor-Faktor yang Mempengaruhi Produktivitas Tenaga Kerja". Survei pada Tenaga Kerja Industri Kecil Tas di Desa Rancasalak Kecamatan Kadungora KabupatenGarut).Bandung.

Peraturan Pemerintah Nomor 121 tahun 2015 tentang Sumber Daya Air

Subyandono, Bambang, 2008, "Pengelolaan Sumber Daya Air Terpadu", Materi Pelatihan Tenaga Ahli Konstruksi Sumber Daya Air, Departemen Pekerjaan Umum, Jakarta

Undang-Undang Nomor 32 Tahun 2009 mengenai Perlindungan dan Pengelolaan Lingkungan Hidup 